\title{
Erratum to: The Economic Knowledge and NATO's Financial Viability
}

\section{Marios Panagiotis Efthymiopoulos}

Published online: 15 February 2011

(C) Springer Science+Business Media, LLC 2011

\section{Erratum to: J Knowl Econ \\ DOI 10.1007/s13132-010-0033-4}

Please note that "Visibility" in the title of this article should read "Viability".

Hence, the correct title of the article is:

The Economic Knowledge and NATO's Financial Viability

The online version of the original article can be found at http://dx.doi.org/10.1007/s13132-010-0033-4.

M. P. Efthymiopoulos ( $\square)$

Strategy International, Thessalonica, Greece

e-mail: marios.efthymiopoulos@strategyinternational.org

M. P. Efthymiopoulos

Center for Transatlantic Relations, SAIS, Johns Hopkins University, Washington, DC, USA 